\title{
Hexagonal Periodicity in the Outer Membrane of Bacteroides buccae
}

\author{
By EERO KEROSUO, 1.2* MARKUS HAAPASALO, ${ }^{2}$ HELENA RANTA 1.4 \\ AND KARI LOUNATMAA 2.3 \\ Departments of ' Cariology, 'Electron Microscopy and ${ }^{3}$ General Microbiology, University of \\ Helsinki, Mannerheimintie 172, SF-00280, Helsinki, Finland \\ ${ }^{+}$National Public Health Institute, Mannerheimintie 166, SF-00280, Helsinki, Finland
}

(Received 27 October 1986; revised 16 February 1987)

\begin{abstract}
In Bacteroides buccae, a hexagonally arranged periodic structure was found in the outer membrane $(\mathrm{OM})$, in addition to hexagonal lattices present in its external surface layer (S-layer). This crystalline OM protein (COMP) was present as patches on the concave fracture face (the outer leaflet) of the $\mathrm{OM}$ in freeze-fractured cells. Occasionally, hexagonally arranged structures could also be seen on the convex fracture face of the OM as 'fingerprints' of the COMP. The OM proteins were isolated and analysed by gel electrophoresis. The major band protein had an apparent molecular mass of $17 \mathrm{kDa}$. Whether the minor band proteins are also components in the structure of the COMP remains to be elucidated. Other oral Gram-negative anaerobic rods studied did not show any periodicity in their OM.
\end{abstract}

\section{INTRODUCTION}

Periodically arranged surface layers, composed of protein or glycoprotein, are found on the cell envelope of numerous bacteria including a few human pathogens (for a review, see Sleytr \& Messner, 1983). The ultrastructure of these protein layers has been studied by electron microscopy using thin sectioning, negative staining (Lounatmaa, 1985) and freeze-etching techniques (Sleytr \& Glauert, 1975), and the periodic structure has been identified as a surface layer (S-layer) external to the peptidoglycan layer in Gram-positive bacteria and external to the outer membrane (OM) in Gram-negative bacteria (Sleytr \& Messner, 1983). By the freezefracture technique the OM of Escherichia coli and Salmonella typhimurium has been shown to be densely packed with intramembranous particles (IMP) (van Gool \& Nanninga, 1971; Smit et al., 1975). These IMP are apparently porins, which are the most intensively studied OM proteins in these two species (for a review, see Nikaido \& Vaara, 1985). When the OM proteins of $E$. coli are treated with sodium dodecyl sulphate (SDS) the porins appear as hexagonal crystals (Rosenbusch, 1974) and a matrix protein has been shown to form a periodic monolayer (Steven et al., 1977). In intact cells of $E$. coli a similar arrangement has not been found (van Gool \& Nanninga, 1971: Nikaido \& Vaara, 1985). There are few reports to show crystalline arrangement of the OM proteins in intact cells. In Chlamydia trachomatis hexagonally arranged granular subunits were first found by negative staining (Zhang et al., 1980) and later by the cryochamber and shadow-cast technique (Chang et al., 1982). Using the freeze-fracture technique, Every and Skerman (1983) found hexagonally arranged crater-like structures on the concave fracture face of the OM of Bacteroides nodosus.

The aim of this study was to describe the ultrastructure of the OM of an oral anaerobic rod, Bacteroides huccae, previously shown to possess a crystalline S-layer (Kornman \& Holt, 1981; Haapasalo et al., 1985: Sjögren et al., 1985). The freeze-fracture studies of one B. buccae strain,

\footnotetext{
Abbreviations: CM, cytoplasmic membrane; COMP, crystalline outer membrane protein; IMP, intramembranous particles; OM, outer membrane: S-layer, surface layer.
} 
ES57, revealed the presence of a crystalline outer membrane protein. For comparison, other $B$. buccae strains and also other oral Gram-negative anaerobic rods were studied.

\section{METHODS}

Strains. Thirteen strains originally isolated from the human oral cavity were studied (Table 1). Laboratory strains were isolated from human dental root canal infections and identified as described previously (Haapasalo et al., 1985, 1986).

Culture methods. Strains from the American Type Culture Collection were obtained as freeze-dried cultures. Laboratory isolates were kept in glycerin-milk at -70 C. All strains were cultured on MCG agar, containing bacteriological agar no. 1 (Oxoid), $5 \%(\mathrm{v} / \mathrm{v})$ horse blood, $0.5 \%(\mathrm{w} / \mathrm{v})$ yeast extract, $0.5 \mathrm{mg}$ menadione $\mathrm{1}^{-1}, 500 \mathrm{mg}$ cysteine $1^{-1}$ and $0 \cdot 2^{\circ}{ }_{0}(\mathrm{w} / \mathrm{v})$ glucose (Haapasalo et al., 1986) in an anaerobic chamber (Anaerobic System, model 1024, Forma Scientific) in an atmosphere of $\mathrm{H}_{2} / \mathrm{CO}_{2} / \mathrm{N}_{2}(10: 5: 85$, by vol. $)$ at $37^{\circ} \mathrm{C}$. Three-day-old cultures after the third or fourth transfer were used for ultrastructural studies.

Electron microscopy. The bacterial cells were collected with a glass rod from the plates into $0.1 \mathrm{M}$-sodium phosphate buffer ( $\mathrm{pH} 7 \cdot 2)$.

For thin sections, the samples were prepared as previously described (Lounatmaa et al., 1976).

For freeze-fracturing, glycerol was added to a final concentration of $30^{\circ} \%(\mathrm{v} / \mathrm{v})$ to facilitate the fracturing through the OM (Lounatmaa \& Nanninga, 1976). The pellet collected by centrifugation $\left(9980 \mathrm{~g}, 20^{\circ} \mathrm{C}, 2 \mathrm{~min}\right.$ ) was frozen in liquid Freon 22 cooled by liquid nitrogen. The fracturing, in a Balzers BAF 400T freeze-etching unit, was done at $-120^{\circ} \mathrm{C}$ and the platinum shadowing at an angle of $40^{\circ}$.

For negative staining, the buffer suspension was allowed to sediment on a grid with a resin film (Pioloform $2295 / 10$. Polaron Equipment Ltd) coated with an additional thin carbon layer and the staining was performed with $2 \%(\mathrm{w} / \mathrm{v})$ phosphotungstic acid (pH 6.5).

The electron micrographs were taken with JEM-100CX (negative staining) and with JEM-1200EX (thin sections and freeze-fracture replicas) transmission electron microscopes at 80 and $60 \mathrm{kV}$, respectively.

Separation of cell wall components. Three-day-old cultures of B. buccae ES57 on MCG agar were collected and gently washed with phosphate buffered saline (PBS: $0.85^{\circ} \mathrm{NaCl}, 0.15 \mathrm{M}$-sodium phosphate, $\mathrm{pH} 7.2$ ). The S-layer was separated from the cells by carefully pipetting the bacterial mass, in PBS, in and out of a $10 \mathrm{ml}$ pipette through a narrow tip (diameter $1.2 \mathrm{~mm}) 20$ times. After centrifugation $\left(9980 \mathrm{~g} .5 \mathrm{~min}, 20^{\circ} \mathrm{C}\right.$ ) the supernatant containing crude S-layer protein was further centrifuged $\left(72000 \mathrm{~g}, 30 \mathrm{~min}, 4^{\circ} \mathrm{C}\right)$. The partly purified S-layer protein was collected from the supernatant and analysed by SDS-PAGE.

After mechanical removal of the S-layer the cells were resuspended in $0.75 \mathrm{M}$-sucrose (10 mM-Tris, $\mathrm{pH} 7.8)$ and the OM proteins were isolated by the procedure described by Osborn et al. (1972) with the modifications of a twofold concentration of lysozyme $\left(20 \mathrm{mg} \mathrm{m}^{-1}\right)$ and a prolonged period of spheroplast formation (Sarvas, 1985). The partly purified OM protein fraction was collected from the sucrose gradient and analysed by SDS-PAGE.

SDS-PAGE. This was done as described by Laemmli (1970).

\section{RESULTS}

Patches consisting of hexagonally arranged IMP were frequently found on the concave fracture faces of the OM of the seven strains of $B$. buccae (Table 1; Figs 1 and 2). The diameter of the patches varied between 50 and $70 \mathrm{~nm}$ but occasionally much larger areas of hexagonally arranged IMP were seen. The size of the patches also varied in the same specimen, being larger at the division zone of the cell (Fig. 1). The centre-to-centre spacing between the individual IMP was always about $8 \mathrm{~nm}$ (Figs 1 and 2). Randomly distributed IMP were observed between adjacent patches and the orientation of the axes of symmetry seemed to be random in adjacent patches (Figs 1 and 2). Usually no periodicity was seen on the convex fracture face of the OM. Occasionally, however, the convex face too showed patches of hexagonally arranged structures and when the inner leaflet of the OM was fractured away another periodic structure was seen (Fig. 3) instead of the typical rough appearance of the convex face of the cytoplasmic membrane.

In thin-sectioned cells of $B$. huccae strains the typical cell envelope structures of Gramnegative bacteria were seen and the presence of an S-layer was confirmed (Fig. 4). No periodicity could be visualized either in the $\mathrm{OM}$ or in the S-layer by this technique.

The freeze-fracture technique sometimes revealed the cross-fractured S-layer as a row of 'pearls' around the cell. The S-layer was not in direct contact with the OM, but there was a gap 


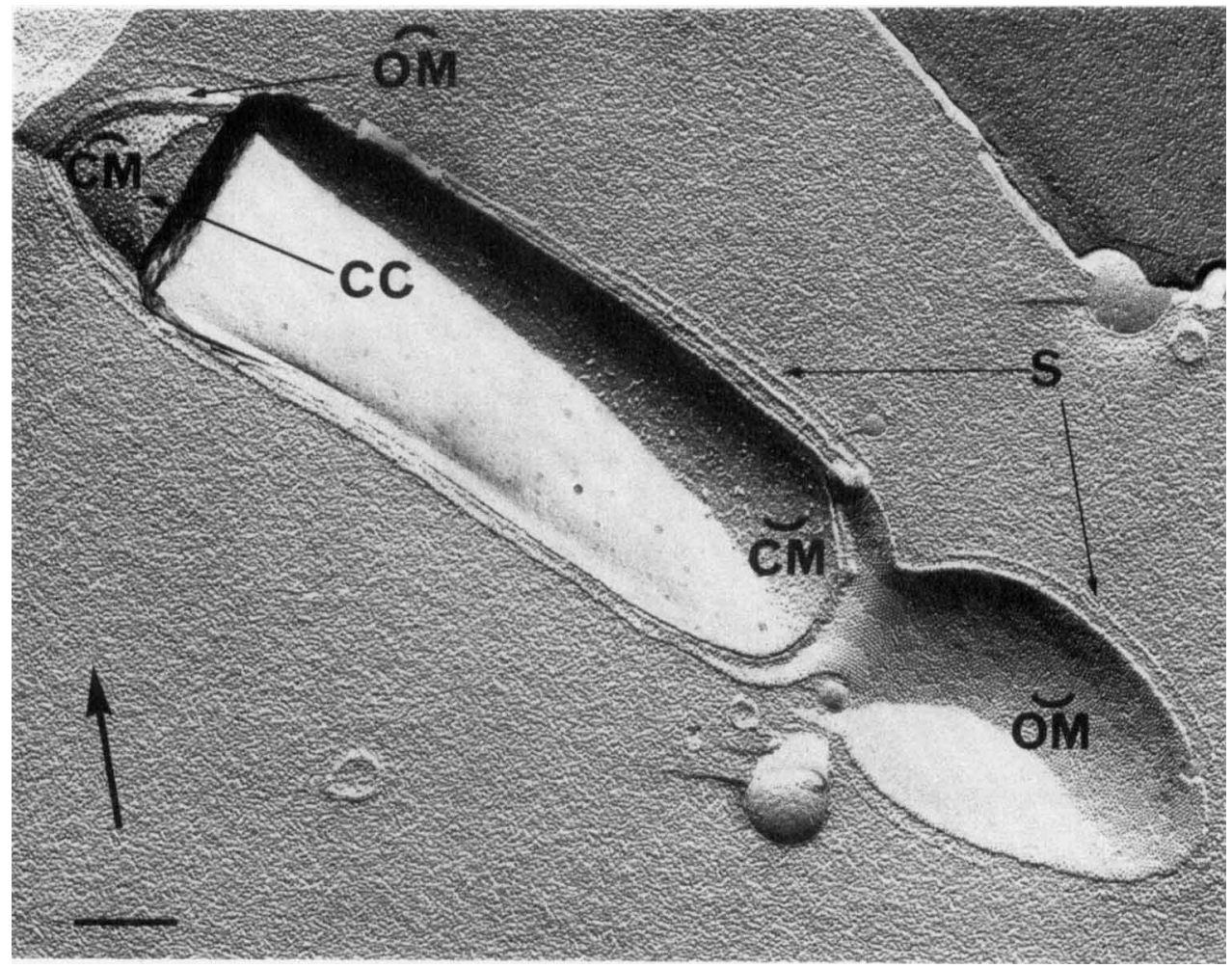

Fig. 1. A freeze-fractured cell of $B$. huccae ES57. All four fracture faces are seen: the convex face of the $C M(\overparen{C M})$, the convex face of the $O M(\overparen{O M})$, the concave face of the $C M(C M)$ and the concave face of the OM (OM): CC, the cell content. The hexagonally arranged IMP form numerous small patches on the OM. Note the division area with larger patches and the cross-fractured S-layer (S) appearing like a necklace around the cell. The direction of shadowing is indicated by an arrow in this and subsequent fracture micrographs. The scale bar represents $0.2 \mu \mathrm{m}$ in this and subsequent micrographs.

\section{Table 1. Sources and sites of isolation of the strains}

Strain Source received from Site of isolation

\section{B. huccue}

ATCC $33574^{\prime}$
ES42
ES57
ES14B
ATCC $336911^{+}$
NP333+
WPH78+
gingiralis
ES 30

$$
\text { ES30 }
$$

B. intermedius

ES63

B. oris

A TCC $33573^{1}$
ATCC 27518
ES2354

ES2354

\section{ESF4}

$\mathrm{ATCC}^{*}$

Own isolate

Own isolate

Own isolate

ATCC

H. Shah

H. Shah

Own isolate

Own isolate

ATCC

ATCC

Own isolate

Own isolate
Gingival sulcus

Root canal

Root canal

Root canal

Subgingival plaque

Dental plaque

Dental plaque

Root canal

Root canal

Gingival sulcus

Human wound

Root canal

Root canal

$T$, type strain.

* American Type Culture Collection.

+ Formerly designated as B. capillus (Kornman \& Holt, 1981: Johnson \& Holdeman, 1985).

‡ Formerly designated as B. pentosaceus (Shah \& Collins, 1981; Johnson \& Holdeman, 1985). 


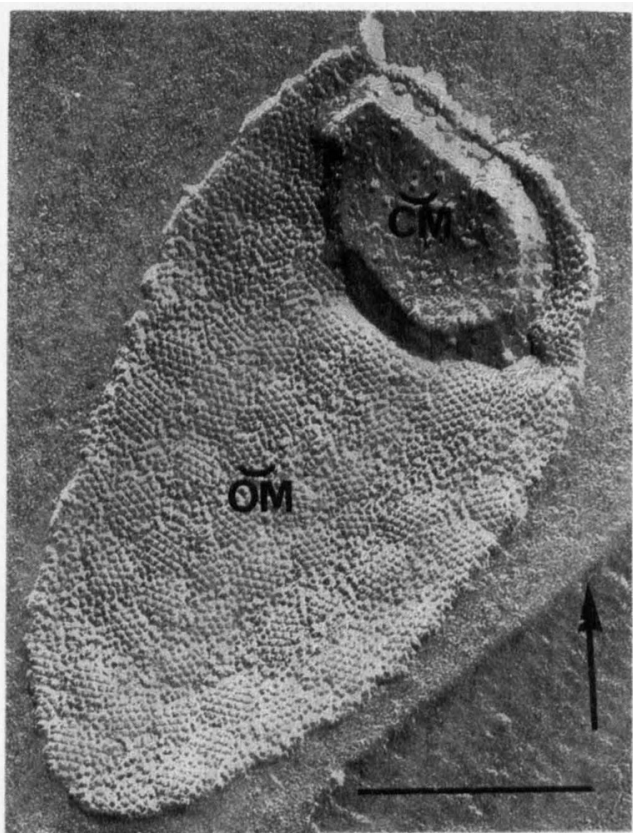

Fig. 2

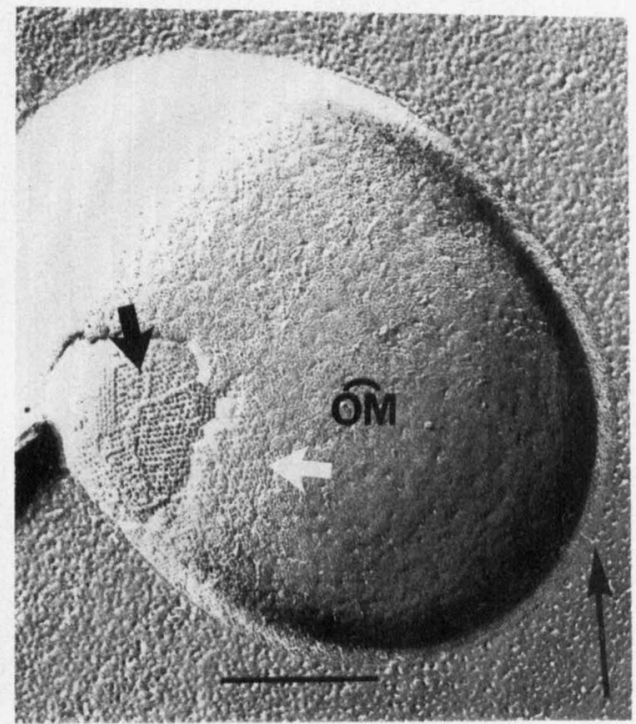

Fig. 3

Fig. 2. A freeze-fractured cell of Bacteroides buccae ES57. Hexagonally arranged IMP are seen as patches on the concave fracture face of the OM $(\widetilde{O M})$. Between the patches the particles are randomly distributed. $\breve{C M}$, the concave fracture face of the $\mathrm{CM}$.

Fig. 3. A freeze-fractured cell of $B$. buccae ES57. A small area of hexagonally arranged structure (white arrow) is visible on the convex fracture face of the OM $(\widehat{\mathrm{OM}})$. The inner leaflet of the $\mathrm{OM}$ is partly broken revealing another net-like structure (short black arrow).

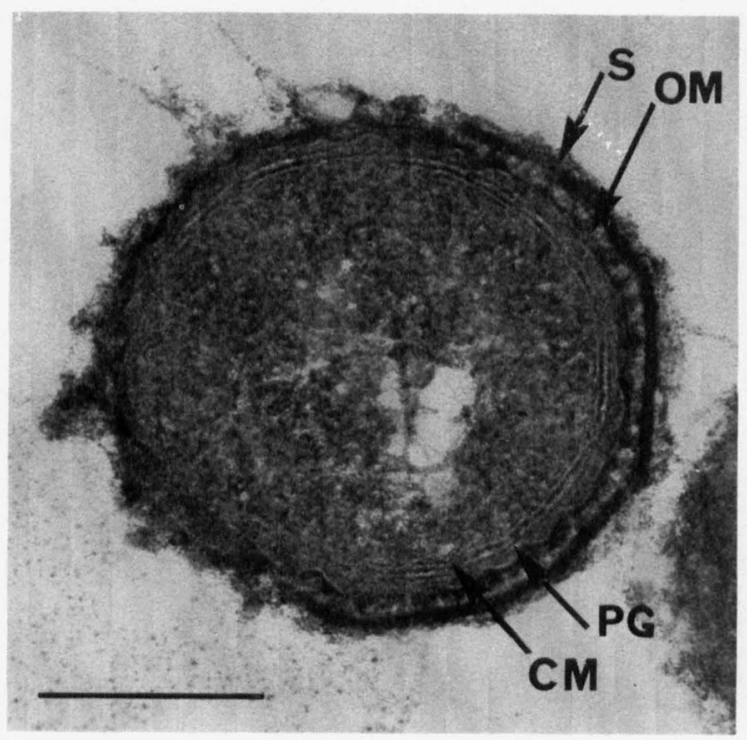

Fig. 4

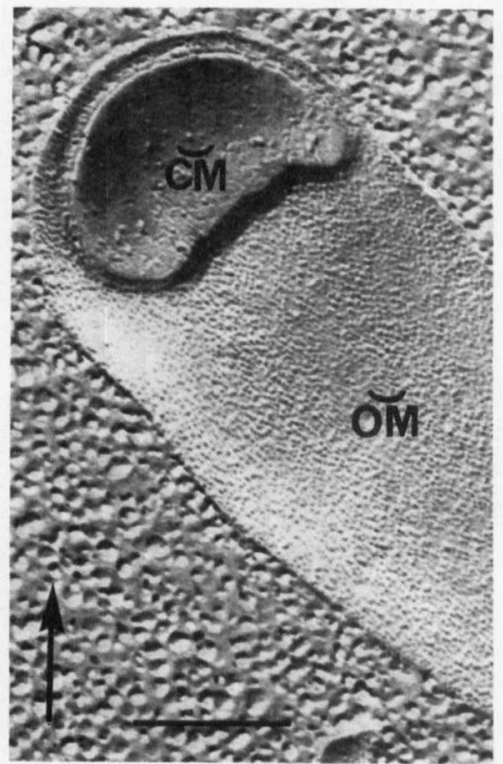

Fig. 5

Fig. 4. The cell envelope of a thin-sectioned cell of B. buccae ES57. The cytoplasmic membrane (CM), the peptidoglycan layer $(\mathrm{PG})$, the outer membrane $(\mathrm{OM})$, and the S-layer $(\mathrm{S})$ are clearly seen.

Fig. 5. A freeze-fractured cell of B. oris ATCC 27518. Randomly distributed IMP on the concave fracture face of the OM $(\breve{O M})$ are visible. 


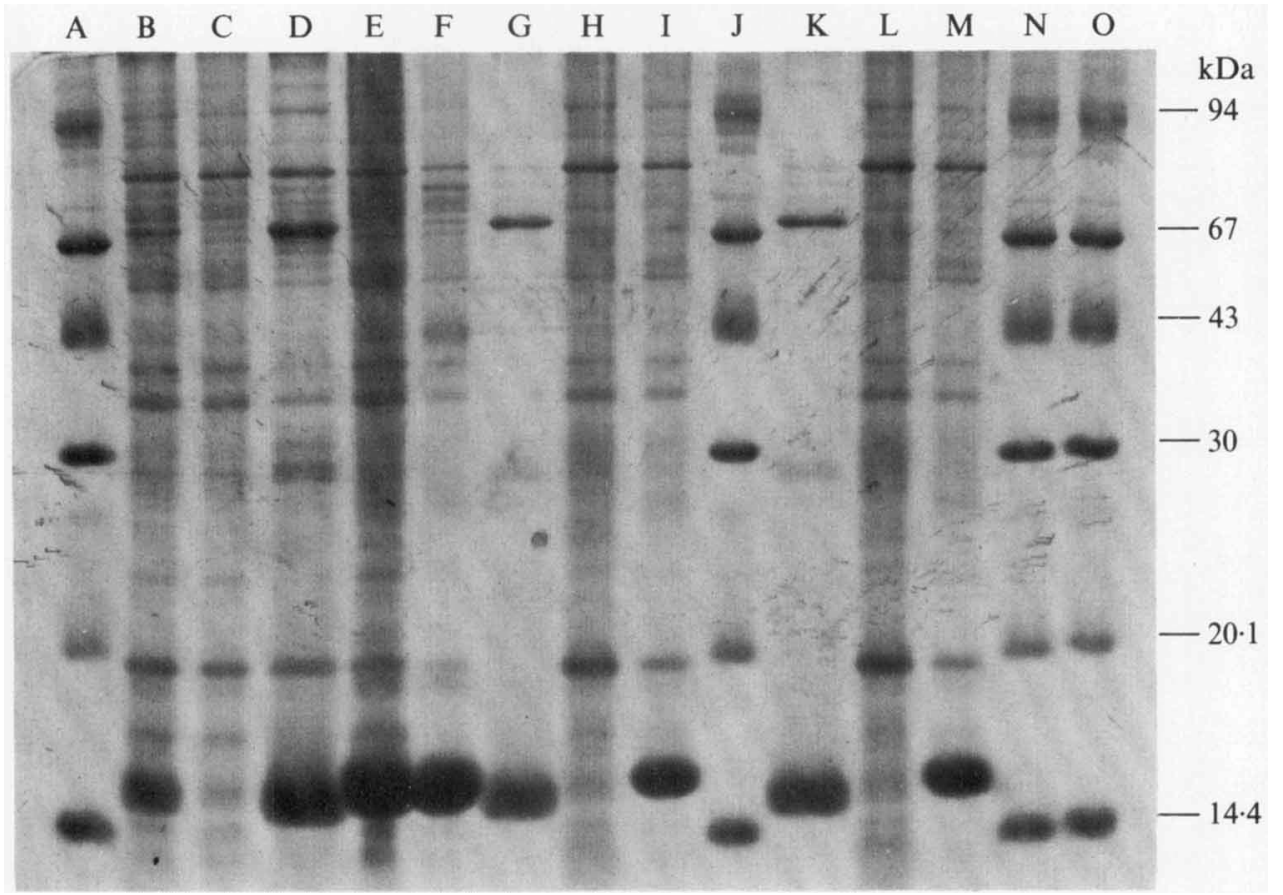

Fig. 6. SDS-PAGE analysis of the cell envelope proteins of B. buccae ES57. Lanes: A, J, N and O, protein standards: $B$, whole cells; $C$, cells after removal of $S$-layer protein by pipetting the bacterial mass, in PBS, in a $10 \mathrm{ml}$ pipette 20 times: $\mathrm{D}$, crude $S$-layer protein after centrifugation $(9980 \mathrm{~g}, 5 \mathrm{~min})$; $E$, broken cells after mechanical removal of S-layer protein; F, crude $O M-C M$ : G and $K$, pure $S$-layer protein after ultracentrifugation $(72000 \mathrm{~g}, 30 \mathrm{~min}) ; \mathrm{H}$ and $\mathrm{L}$, partly purified $\mathrm{CM}$ from the sucrose gradient; I and $\mathbf{M}$, partly purified $\mathrm{OM}$ from the sucrose gradient.

(about $20 \mathrm{~nm}$ ) between these two outermost cell envelope structures (Fig. 1), corresponding to the alignment of these structures in a thin-sectioned cell (Fig. 4).

No periodic structures were found when the strains of $B$. gingivalis, $B$. intermedius, $B$. oris and Fusobacterium nucleatum (Table 1) were freeze-fractured. The IMP were randomly distributed also on the concave fracture face of the OM (Fig. 5).

On SDS-PAGE the partly purified OM preparation of $B$. buccae ES57 showed one major band with an apparent molecular mass of about $17 \mathrm{kDa}$ (Fig. 6, lane I) and a few other, minor, bands with higher molecular masses. The partly purified S-layer preparation (Fig. 6, lane G) showed three major bands, one of about $70 \mathrm{kDa}$ and a double band of about $16 \mathrm{kDa}$. The $70 \mathrm{kDa}$ band was also present in the whole-cell preparation (Fig. 6, lane B) but not in the OM preparation (Fig. 6, lane I).

\section{DISCUSSION}

The OM of Gram-negative bacteria is an asymmetrical membrane composed of lipopolysaccharide and a large amount of protein (Nikaido \& Vaara, 1985). When the cell is freeze-fractured, numerous IMP are seen on the concave fracture face of the OM. Since in mutants of $S$. typhimurium and E. coli lacking one or more of the major OM proteins these IMP are absent or reduced in density in micrographs, they are considered to be composed of complexes of the OM proteins (Smit et al., 1975; Verkleij et al., 1977; Lounatmaa, 1979). Consequently, the hexagonally arranged IMP found in this study on the concave fracture faces of the OM (Figs 1 and 2) are assumed to be complexes of proteins, thus tentatively named crystalline outer membrane protein (COMP). A schematic illustration is shown in Fig. 7. 


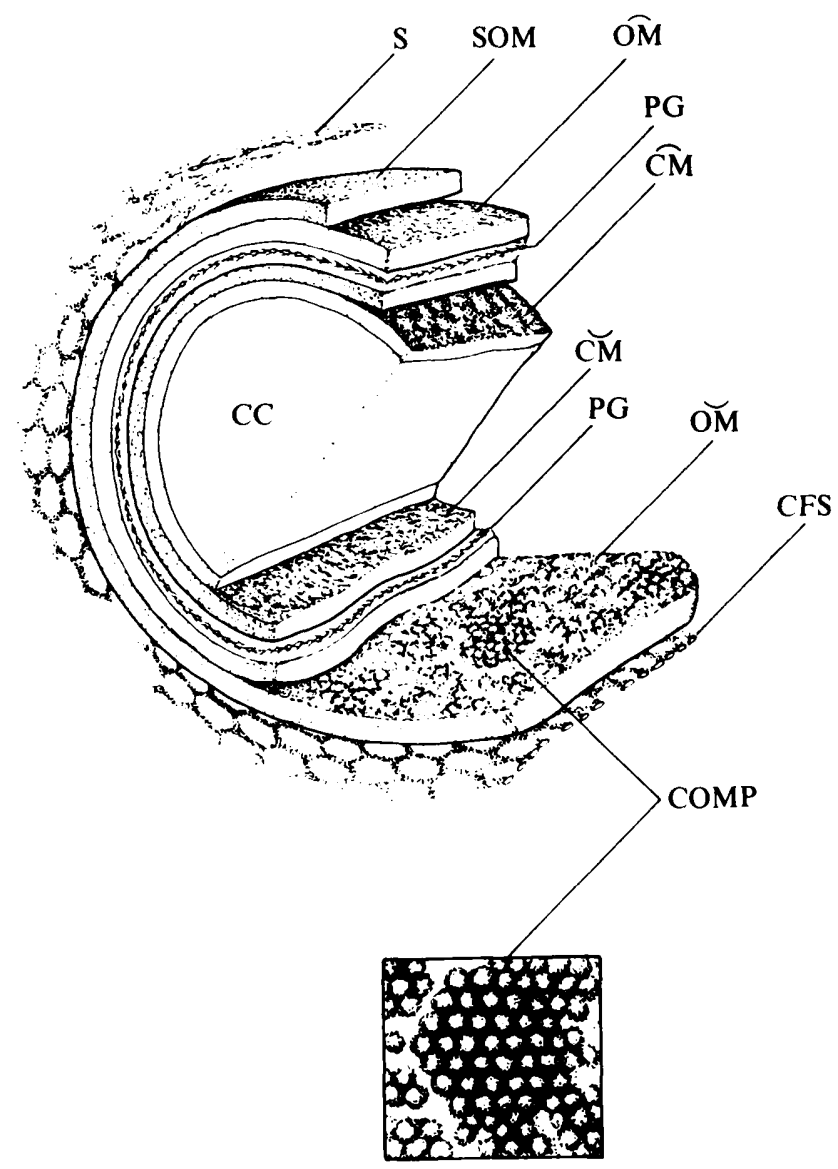

Fig. 7. Schematic illustration of the ultrastructure of the cell envelope of $B$. buccae ES57 as visualized by the freeze-fracture technique. The dimensions are arbitrary. The surface of the OM (SOM) and the lipopolysaccharide covering the cell (not indicated) are not visualized by this technique. OM, convex face of the OM; PG, peptidoglycan; $\overparen{C M}$, convex face of the CM; $\breve{C M}$, concave face of the CM; $\breve{O M}$, concave face of the OM: COMP, crystalline outer membrane protein; S, S-layer; CFS, cross-fractured S-layer; CC, cell content.

The crystalline structures (Fig. 3) which were occasionally found on the convex fracture face of the OM are probably 'fingerprints' of the COMP from the outer leaflet of the OM. It is not known whether the other crystalline structure exposed after the incomplete breakage of the inner leaflet of the OM (Fig. 3) represents peptidoglycan.

The centre-to-centre spacing (about $8 \mathrm{~nm}$ ) of the COMP of B. buccae found in this study differs distinctly from those reported for crystalline $O M$ lattices in $C$. trachomatis $(17.5 \mathrm{~nm})$ (Chang et al., 1982) and B. nodosus (20 nm) (Every \& Skerman, 1983).

For the first time, both the S-layer and the COMP were found in the same strains. In $B$. nodosus, a hexagonal protein lattice in the $\mathrm{OM}$ was detected only in a strain lacking the S-layer (Every \& Skerman, 1983) and the C. trachomatis strain studied by Chang et al. (1982) did not possess an S-layer.

The structural relationship between the S-layer and the COMP is interesting. The centre-tocentre spacing found in the COMP (about $8 \mathrm{~nm}$ ) is very close to that found in the smaller S-layer lattice $(7.7 \mathrm{~nm})$ in the same species (Sjögren et al., 1985). However, it cannot be excluded that the cell-wall components, interpreted as S-layer by Sjögren et al. (1985) are supported by OM fragments. Thus, it is possible that the $7.7 \mathrm{~nm}$ lattice in fact represents the COMP lattice found in this study. The $21.5 \mathrm{~nm}$ lattice represents the S-layer, which has also been visualized by freeze- 
etching (Ranta et al., 1983). Fracturing without etching rarely exposes S-layer surfaces (Sleytr \& Messner, 1983); thus in this study the S-layer appeared cross-fractured (Fig. 1). The SDS-PAGE analysis showed that the band of about $17 \mathrm{kDa}$ was present among the OM proteins and not even as a minor band among the S-layer proteins (Fig. 6, lanes $\mathrm{G}$ and I). It is possible that the $17 \mathrm{kDa}$ polypeptide found in this study is the main component of the COMP. Whether the minor band proteins found (Fig. 6, lane I) are also components of the structure of the COMP remains to be elucidated.

Several OM proteins are known to be associated with resistance to antibiotics (Nikaido \& Vaara, 1985) and with important virulence factors (Paakkanen et al., 1979; Carter et al., 1980) but these proteins are not known to form crystals (Kapperud et al., 1985; Zaleska et al., 1985). So far, the S-layers are the most intensively studied crystalline protein layers but their function is still poorly understood. In several species the S-layer proteins are known to have a molecularsieve function, which protects the cell against lytic enzymes (Sleytr \& Messner, 1983). However, S-layer was not found to be related to immunoprotection in B. nodosus (Every \& Skerman, 1983). Also, the function of the COMP found in this study is not clear.

We thank Dr Haroun Shah for kindly providing us with two reference strains, Ms Tuire Koro, Ms Sirkka Saario and Mr Jouko Sund vall for skilled technical assistance, and Ms Martta Pyykkö and Mr Matti Moisio for designing and sketching the schematic illustration.

This study was financially supported by the University of Helsinki (to K. L. and H.R.) and by the Finnish Dental Society (to E.K.).

\section{REFERENCES}

Carter, P. B., Zahorchak, R. J. \& Brubaker, R. R. (1980). Plaque virulence antigens from Yersinia enterocolitica. Infection and Immunity 28, 638-640.

Chang, J. J., Leonard, K., Arad, D., Pitt, T., Zhang, Y. X. \& ZhaNG, L. H. (1982). Structural studies of the outer envelope of Chlamydia trachomatis by electron microscopy. Journal of Molecular Biology 161, 579-590.

EVERY, D. \& SKeRMAN, T. M. (1983). Surface structure of Bacteroides nodosus in relation to virulence and immunoprotection in sheep. Journal of General Microbiology' 129, 225-234.

van Gool, A. P. \& Nanninga, N. (1971). Fracture faces in the cell envelope of Escherichia coli. Journal of Bacteriology 108, 474-481.

haapasalo, M., lounatmaa, K., Ranta, H., Shah, H. \& RANTA, K. (1985). Ultrastructure of Bacteroides capillus, B. buccae, B. pentosaceus, B. oris, B. oralis, $B$. veroralis, and pentose sugar-fermenting Bacteroides sp. from humans with periapical osteitis: occurrence of external proteinaceous cell wall layer. International Journal of Systematic Bacteriology 35, 65-72.

Haapasalo, M., Ranta, H., Shah, H., Ranta, K., LounatmaA, K. \& Kroppenstedt, R. M. (1986). Biochemical and structural characterization of an unusual group of Gram-negative, anaerobic rods from human periapical osteitis. Journal of General Microbiolog! 132, 417-426.

Johnson, J. L. \& Holdeman, L. V. (1985). Bacteroides capillus Kornman and Holt and Bacteroides pentosaceus Shah and Collins, later synonyms of Bacteroides buccae Holdeman et al. International Journal of Systematic Bacteriolog. 35, 114.

Kapperud, G., Namork, E. \& SKarpeid, H.-J. (1985). Temperature-inducible surface fibrillae associated with the virulence plasmid of Yersinia enterocolitica and Yersinia pseudotuberculosis. Infection and Immunity 47, 561-566.
Kornman, K. S. \& Holt, S. C. (1981). Physiological and ultrastructural characterization of a new Bacteroides species (Bacteroides capillus) isolated from severe localized periodontitis. Journal of Periodontal Research 16, 542-555.

LAEMMLI, U. K. (1970). Cleavage of structural proteins during the assembly of the head of bacteriophage T4. Nature, London 227, 680-685.

LOUNATMAa, K. (1979). Ultrastructure of the outer membrane of Salmonella typhimurium bacteriocinresistant mutants deficient in the $33 \mathrm{~K}$ protein. Journal of Bacteriology 139, 646-651.

LOUNATMAA, K. (1985). Electron microscopic methods for the study of bacterial surface structures. In Enterobacterial Surface Antigens: Methods for Molecular Characterization, pp. 243-261. Edited by T. K. Korhonen, E. A. Dawes \& P. H. Mäkelä. Amsterdam: Elsevier.

LounatmaA, K. \& NanNinga, N. (1976). Effect of polymyxin on the outer membrane of Salmonella typhimurium: freeze-fracture studies. Journal of Bacteriology 128, 665-667.

Lounatmaa, K., Mäkelä, P. H. \& Sarvas, M. (1976). The effect of polymyxin on the outer membrane of Salmonella. Ultrastructure of wild type and polymyxin resistant strains. Journal of Bacteriology 127 , 1400-1407.

NikaIdo, H. \& VAaRA, M. (1985). Molecular basis of bacterial outer membrane permeability. Microbiological Reviews 49, 1-32.

Osborn, M. J., Gander, J. E., Parisi, E. \& Carson, J. (1972). Mechanism of assembly of the outer membrane of Salmonella typhimurium. Isolation and characterization of cytoplasmic and outer membrane. Journal of Biological Chemistry 247, 3962 3972.

PaAkKanen, J., Gotschlich, E. C. \& Mäkelä, P. H. (1979). Protein $K$ : a new major outer membrane 
protein found in encapsulated Escherichia coli. Journal of Bacteriology 139, 835-841.

Ranta, H., LounatmaA, K., HaApasalo, M. \& Ranta, K. (1983). Isolation and ultrastructure of Bacteroides sp. with external cell-wall layer (S-layer) in periapical osteitis. Scandinarian Journal of Dental Research 91, 458-464.

RosENBUSCH, J. (1974). Characterization of the major envelope protein from Escherichia coli. Regular arrangement on the peptidoglycan and unusual dodecyl sulfate binding. Journal of Biological Chemistry 249, 8019-8029.

SaRvas, M. (1985). Membrane fractionation methods. In Enterobacterial Surface Antigens: Methods for Molecular Characterization, pp. 111-122. Edited by T. K. Korhonen, E. A. Dawes \& P. H. Mäkelä. Amsterdam: Elsevier.

Shah, H. N. \& Collins, M. D. (1981). Bacteroides buccalis, sp. nov., Bacteroides denticola, sp. nov., and Bacteroides pentosaceus, sp. nov., new species of the genus Bacteroides from the oral cavity. Zentralblatt für Bakteriologie, Parasitenkunde, Infektionskrankheiten und Hygiene, Abteilung 1, Orig. Reihe C 2, 235 241.

Sjögren, A., Hovmöller, S., Farrants, G., Ranta, H., HaApasalo, M., Ranta, K. \& LounatmaA, K. (1985). Structures of two different surface layers found in six Bacteroides strains. Journal of Bacteriology 164, 1278-1282.

Sleytr, U. B. \& Glauert, A. M. (1975). Analysis of regular arrays of subunits on bacterial surfaces; evidence for a dynamic process of assembly. Journal of Ultrastructure Research 50, 100-116.

Sleytr, U. B. \& Messner, P. (1983). Crystalline surface layers on bacteria. Annual Reriew of Microbiolog. 7, 311-339.

Smit, J., Kamio, Y. \& NiKaido, H. (1975). Outer membrane of Salmonella typhimurium. Chemical analysis and freeze-fracture studies with lipopolysaccharide mutants. Journal of Bacteriology 124, 942 958.

Steven, A. C., ten Heggeler, B., Müller, R., Kistler, J. \& RosenbusCH, J. P. (1977). Ultrastructure of a periodic protein layer in the outer membrane of Escherichia coli. Journal of Cell Biology 72, 292-301.

VerkleiJ, A., van Alphen, L., Bijvelt, J. \& LugtenBERG, B. (1977). Architecture of the outer membrane of Escherichia coli K-12. II. Freeze-fracture morphology of wild type and mutant strains. Biochimica et biophysica acta 466, 269-282.

Zaleska, M., LounatmaA, K., Nurminen, M., WahlSTRÖM, E. \& MÄKELÄ, P. H. (1985). A novel virulence-associated cell surface structure composed of $47-\mathrm{kD}$ protein subunits in Yersinia enterocolitica. EMBO Journal 4, 1013-1018.

Zhang, Y., Meng, X., Zhang, L., Su, H. \& LI, R. (1980). Studies on the ultrastructure of envelope of elementary bodies of Chlamydia trachomatis. Scientia Sinica 23, $1208-1215$. 